\title{
Study on Quantity and Quality Aspects of the Drain Water of Nallamada Drain in Krishna Western Delta
}

\author{
A. Rama Rao ${ }^{1 *}$ and M. Raghu Babu ${ }^{2}$ \\ ${ }^{1}$ Krishi Vigyan Kendra, Kondempudi, Visakhapatnam, India \\ ${ }^{2}$ Acharya N.G. Ranga Agricultural University, India \\ *Corresponding author
}

\section{A B S T R A C T}

\section{Keywords \\ Quantity and quality aspects, Nallamada drain, Western delta \\ Article Info \\ Accepted: \\ 15 September 2018 Available Online: 10 October 2018}

\begin{abstract}
The Nallamada Drain flows were observed during September to December month i.e. in the tune of $3-4.5$ TMC. During January to April and August months the outflow quantities were to the tune of 0.5 to $1.5 \mathrm{TMC}$. It was estimated that on an average about 43.84 TMC of water flows through the drain annually. The Electrical Conductivity of drain water up to the end of March, 2009 was less than $1.0 \mathrm{dS} / \mathrm{m}$ indicated that the water was fit for irrigation. The $\mathrm{pH}$ values of the drain water was estimated to be below 8.0 up to December 2008 and reached to greater than 8.0 and below 9.0 during January 2009 March 2009. SAR values were within the safer limit of less than 10.0 and RSC was less than 2.50 meq/l during September 2008 to March 2009.
\end{abstract}

\section{Introduction}

In Krishna Western Delta, Nallamada drain is located up-stream end at Vogeru near Chilakulurupet, $60.5 \mathrm{Km}$ length to the downstream end at zero face of the Bapatla jurisdiction close to sea mouth.

Nallamada drain water is the major source of irrigation for Narasaraopet and Pedanandipadu belt, where commercial crops like Cotton, Maize, Chilli, Tobacco and Bengal gram are cultivated in both kharif and rabi seasons. There are 64 Lift Irrigation Schemes established in Nallamada drain command, covering an extent of about 20,000 ha, each scheme covering a range of minimum of 15.6 ha to maximum of 3200 ha.

\section{Review of Literature}

Purushothama et al., (2005) analysed physico - chemical characteristics of the Keladi tank water at sagar taluk in Shimoga district, Karnataka, India, were studied from January to December 2004. The water temperature recorded ranged between $25-30^{\circ} \mathrm{C}$, the minimum temperature was encountered in September and maximum in March. The $\mathrm{pH}$ of the water was slightly acidic to alkaline, ranging from 6.5 to 8.5 . The electrical conductivity was observed approximately 57 to $138 \mathrm{micro} \mathrm{mhos} / \mathrm{cm}$.

Singandhupe and Madhulika (2005) conducted experiment on estimation of reference evapotranspiration and crop coefficient in 
commercial crops under semi-arid environment in India. They revealed that the $\mathrm{ET}_{\mathrm{o}}$ estimates obtained from six commonly used $\mathrm{ET}_{\mathrm{O}}$ estimation models indicated that under semi-arid climatic conditions, the Hargreaves method was found highly acceptable for computing reference $\mathrm{ET}_{\mathrm{o}}$ due to minimum root mean square error and mean bias error. This method also resulted in minimum variation of $\mathrm{ET}_{\mathrm{o}}$ (overestimated by $6.54 \%$ ) as compared to the remaining models.

Vijay-Kumar et al., (2005) collected water quality samples during 1999-2000 from three selected irrigation sources, two of them on minor lift irrigation schemes (LIS) (Bhor LIS (BLIS) and Chatha LIS (CLIS)) on perennial streams fed by municipal/ industrial effluents from Jammu City, and one Gidargalian LIS (GLIS) from a canal originating from the Chenab River. These samples were analyzed with the objectives of monitoring the physicochemical characteristics of the water and comparing the water quality of different sources and to evaluate the suitability of water for irrigation.

\section{Materials and Methods}

The data on flows of Nallamada drain during 2005-09, recorded daily at Returu gauging station, Guntur district of Andhra Pradesh were procured from Department of Hydrology, Hyderabad and analysed.

\section{Water quality assessment}

The quality and type of mineral matter dissolved, depends on the chemical composition and physical structure of the rocks as well as the hydrogen ion concentration $(\mathrm{pH})$ and the redox potential (Eh) of the water. The ability of water to dissolve minerals, determines the chemical nature of the drain water. A constant monitoring of chemical parameters throughout the year in all seasons is therefore required for any regional hydro chemical studies and hence sampling is required to be done at regular time intervals. The $\mathrm{pH}$ of drain water tested by systronics $\mathrm{pH}$ system 361 and Electrical conductivity was tested by systronics conductivity TDS meter 307. (AICRP, BIENNIAL REPORT 2008-2010), Bapatla and discussed in chapter

\section{Results and Discussion}

\section{Quantification of drain water flow in Nallamada drain}

Though rainfall affects the drain flow quantity, for close observation over the years, month wise total quantity of drain flows for the years 2005-06, 2006-07, 2007-08 and 2008-09 are individually tabulated in Tables 1 , 2, 3, 4 and 5 respectively. The same data are represented pictorially in the form of histograms for easy understanding in Figures 1, 2, 3, 4 and 5 respectively. From all the years of the data of drain flow quantities, it is observed that during the months of May there were meagre or no out flows in the drain. As per the interaction with the farmers, the fields were kept without crop during this period. Peak outflow in all the years was observed in the month of November. High drain flows were observed during September to December month i.e. in the tune of $3-4.5$ TMC. During January to April and August months the outflows were in the tune of 0.5 to $1.5 \mathrm{TMC}$.

From the above table, it is observed that on an average about 43.84 TMC of water flows through the drain annually. But perhaps in the year 2005-06, very less drain flow was observed because of low drain flow due to deficit rainfall in the NSP command.

It was found from the Table 5 the total quantity of water flow in Nallamada command in a year was 43.84 TMC. Out of which only 6 
TMC of water could be used for all the LI schemes and for all the crops under Nallamada command in Krishna Western Delta. The remaining 37.84 TMC of quantity of water joined with sea.

\section{Quality of drain water}

The analyses of the quality of drain water for various constituents were carried out at the laboratories of Saline Water Scheme, Bapatla and presented in brief in this sub section.

\section{Water analysis of Nallamada drain}

During 2008-09, drain water samples were collected periodically from Nallamada drain from different locations viz., Kondpaturu, Pedanandipadu and Returu and also from Krishna western canal at Appapuram and analysed for $\mathrm{EC}, \mathrm{pH}, \mathrm{CO}_{3}, \mathrm{HCO}_{3}, \mathrm{Cl}, \mathrm{SO}_{4}, \mathrm{Ca}$, $\mathrm{Mg}, \mathrm{Na}$ and $\mathrm{K}$. The data shows that the Electrical Conductivity of drain water up to the end of March, 2009 was less than $1.0 \mathrm{dS} / \mathrm{m}$ and water was fit for irrigation.

The perusal of data indicated that $\mathrm{pH}$ values of the drain water was estimated to be below 8.0 up to December 2008 and reached to more than 8.0 and below 9.0 during January 2009 March 2009. SAR values were within the safer limit of less than 10.0 and RSC was less than $2.50 \mathrm{meq} / \mathrm{l}$ during September 2008 - March 2009 (Table 6).

Drain flows were observed and concluded that during September to December month i.e. in the tune of $3-4.5$ TMC. During January to April and August months the outflows were in the tune of 0.5 to $1.5 \mathrm{TMC}$

Table.1 Flow quantities of Nallamada drain during 2005-06

\begin{tabular}{|c|c|c|c|c|}
\hline S. No & Month & $\begin{array}{c}\text { Monthly Quantity } \\
\text { (Cu. m) }\end{array}$ & $\begin{array}{c}\text { Quantity } \\
\text { (TMC) }\end{array}$ & $\begin{array}{c}\text { Cumulative Quantity } \\
\text { (TMC) }\end{array}$ \\
\hline 1 & 6 & 0 & 0.00 & 0.00 \\
\hline 2 & 7 & 0 & 0.00 & 0.00 \\
\hline 3 & 8 & 33295104 & 1.18 & 1.18 \\
\hline 4 & 9 & 91349856 & 3.23 & 4.40 \\
\hline 5 & 10 & 103014720 & 3.64 & 8.04 \\
\hline 6 & 11 & 121373856 & 4.29 & 12.32 \\
\hline 7 & 12 & 95535936 & 3.37 & 15.70 \\
\hline $\mathbf{8}$ & 1 & 16993152 & 0.60 & 16.30 \\
\hline 9 & 2 & 21187008 & 0.75 & 17.05 \\
\hline 10 & 3 & 36741600 & 1.30 & 18.34 \\
\hline 11 & 4 & 19058112 & 0.67 & 19.02 \\
\hline 12 & 5 & 0 & 0.00 & 19.02 \\
\hline Total & $\mathbf{1 2}$ & $\mathbf{5 3 8 5 4 9 3 4 4}$ & $\mathbf{1 9 . 0 2}$ & $\mathbf{1 9 . 0 2}$ \\
\hline
\end{tabular}


Table.2 Flow quantities of Nallamada drain during 2006-07

\begin{tabular}{|c|c|c|c|c|}
\hline S. No & Month & Monthly Quantity $(\mathbf{C u} . \mathbf{m})$ & Quantity (TMC) & Cumulative Quantity (TMC) \\
\hline $\mathbf{1}$ & 6 & 4500576 & 0.16 & 0.16 \\
\hline $\mathbf{2}$ & 7 & 26396064 & 0.93 & 1.09 \\
\hline $\mathbf{3}$ & 8 & 47085408 & 1.66 & 2.75 \\
\hline 4 & 9 & 222087744 & 7.84 & 10.60 \\
\hline $\mathbf{5}$ & 10 & 213635232 & 7.54 & 18.14 \\
\hline $\mathbf{6}$ & 11 & 368514144 & 13.01 & 31.15 \\
\hline $\mathbf{7}$ & 12 & 149533344 & 5.28 & 36.43 \\
\hline $\mathbf{8}$ & 1 & 123176160 & 4.35 & 40.78 \\
\hline $\mathbf{9}$ & 2 & 73843488 & 2.61 & 43.39 \\
\hline $\mathbf{1 0}$ & 3 & 57056832 & 2.01 & 45.40 \\
\hline $\mathbf{1 1}$ & 4 & 84603744 & 2.99 & 48.39 \\
\hline $\mathbf{1 2}$ & 5 & 8532864 & 0.30 & 48.69 \\
\hline Total & $\mathbf{1 2}$ & $\mathbf{1 3 7 8 9 6 5 6 0 0}$ & $\mathbf{4 8 . 6 9}$ & $\mathbf{4 8 . 6 9}$ \\
\hline
\end{tabular}

Table.3 Flow quantities of Nallamada drain during 2007-08

\begin{tabular}{|c|c|c|c|c|}
\hline S. No & Month & Monthly Quantity $(\mathbf{C u} . \mathbf{m})$ & Quantity (TMC) & Cumulative Quantity (TMC) \\
\hline $\mathbf{1}$ & 6 & $\mathbf{7 2 6 3 9 9 3 6}$ & 2.56 & 2.56 \\
\hline $\mathbf{2}$ & 7 & 40295232 & 1.42 & 3.98 \\
\hline $\mathbf{3}$ & 8 & 171052128 & 6.04 & 10.02 \\
\hline $\mathbf{4}$ & 9 & 391055904 & 13.81 & 23.83 \\
\hline $\mathbf{5}$ & 10 & 254263968 & 8.98 & 32.81 \\
\hline $\mathbf{6}$ & 11 & 149068512 & 5.26 & 38.07 \\
\hline $\mathbf{7}$ & 12 & 122641344 & 4.33 & 42.40 \\
\hline $\mathbf{8}$ & 1 & 73706976 & 2.60 & 45.01 \\
\hline $\mathbf{9}$ & 2 & 108318816 & 3.82 & 48.83 \\
\hline $\mathbf{1 0}$ & 3 & 72950112 & 2.58 & 51.41 \\
\hline $\mathbf{1 1}$ & 4 & 35730720 & 1.26 & 52.67 \\
\hline $\mathbf{1 2}$ & $\mathbf{5}$ & 0 & 0.00 & 52.67 \\
\hline Total & $\mathbf{1 2}$ & $\mathbf{1 4 9 1 7 2 3 6 4 8}$ & $\mathbf{5 2 . 6 7}$ & $\mathbf{5 2 . 6 7}$ \\
\hline
\end{tabular}

Table.4 Flow quantities in Nallamada drain during 2008-09

\begin{tabular}{|c|c|c|c|c|}
\hline S. No & Month & Monthly Quantity (Cu. m) & Quantity (TMC) & Cumulative Quantity (TMC) \\
\hline $\mathbf{1}$ & 6 & 13275360 & 0.47 & 0.47 \\
\hline $\mathbf{2}$ & 7 & 6968160 & 0.25 & 0.72 \\
\hline $\mathbf{3}$ & 8 & 164847744 & 5.82 & 6.54 \\
\hline $\mathbf{4}$ & 9 & 151584480 & 5.35 & 11.89 \\
\hline $\mathbf{5}$ & 10 & 211615200 & 7.47 & 19.36 \\
\hline $\mathbf{6}$ & 11 & 319139136 & 11.27 & 30.63 \\
\hline $\mathbf{7}$ & 12 & 238363776 & 8.42 & 39.05 \\
\hline $\mathbf{8}$ & 1 & 102926592 & 3.63 & 42.68 \\
\hline $\mathbf{9}$ & 2 & 118250496 & 4.18 & 46.86 \\
\hline $\mathbf{1 0}$ & 3 & 99723744 & 3.52 & 50.38 \\
\hline $\mathbf{1 1}$ & 4 & 97087680 & 3.43 & 53.81 \\
\hline $\mathbf{1 2}$ & 5 & 32864832 & 1.16 & 54.97 \\
\hline Total & $\mathbf{1 2}$ & $\mathbf{1 5 5 6 6 4 7 2 0 0}$ & $\mathbf{5 4 . 9 7}$ & $\mathbf{5 4 . 9 7}$ \\
\hline
\end{tabular}


Table.5 Year wise Nallamada drain flow quantities during 2005-09

\begin{tabular}{|c|c|c|c|}
\hline S. No. & Year & Yearly Flow Quantity (Cu. m) & Quantity (TMC) \\
\hline 1 & $2005-06$ & 538549344 & 19.02 \\
\hline 2 & $2006-07$ & 1378965600 & 48.69 \\
\hline 3 & $2007-08$ & 1491723648 & 52.67 \\
\hline 4 & $2008-09$ & 1556647200 & 54.97 \\
\hline
\end{tabular}

Table.6 EC, pH and SAR of Nallamada drain water

\begin{tabular}{|c|c|c|c|c|}
\hline Date of sample Collection & Name of location & $\mathrm{EC}_{\mathrm{iw}} \mathrm{dS} / \mathrm{m}$ & pH & SAR (mmole/1) \\
\hline \multirow[t]{4}{*}{$26-09-2008$} & Kondpaturu (D) & 0.85 & 7.03 & 2.10 \\
\hline & Pedanandipadu (D) & 0.88 & 7.48 & 3.00 \\
\hline & Returu (D) & 0.65 & 7.54 & 2.90 \\
\hline & Kommamuru (Canal) & 0.49 & 7.40 & 1.33 \\
\hline \multirow[t]{4}{*}{04.12 .2008} & Kondpaturu (D) & 0.76 & 7.97 & 2.70 \\
\hline & Pedanandipadu (D) & 0.82 & 7.93 & 3.30 \\
\hline & Returu (D) & 0.70 & 7.51 & 2.45 \\
\hline & Kommamuru (Canal) & 0.61 & 7.97 & 0.13 \\
\hline \multirow[t]{4}{*}{06.01 .2009} & Kondpaturu (D) & 0.83 & 8.13 & 0.50 \\
\hline & Pedanandipadu (D) & 0.83 & 7.92 & 2.66 \\
\hline & Returu (D) & 0.70 & 8.14 & 2.24 \\
\hline & Kommamuru (Canal) & 0.59 & 8.43 & 2.05 \\
\hline \multirow[t]{4}{*}{16.01 .2009} & Kondpaturu (D) & 0.89 & 8.32 & 3.30 \\
\hline & Pedanandipadu (D) & 0.85 & 8.21 & 2.98 \\
\hline & Returu (D) & 0.55 & 8.58 & 1.26 \\
\hline & Kommamuru (Canal) & 0.53 & 8.30 & 1.20 \\
\hline \multirow[t]{4}{*}{10.02 .2009} & Kondpaturu (D) & 0.84 & 8.25 & 0.58 \\
\hline & Pedanandipadu (D) & 0.82 & 8.45 & 0.52 \\
\hline & Returu (D) & 0.77 & 8.36 & 3.40 \\
\hline & Kommamuru (Canal) & 0.61 & 8.00 & 1.98 \\
\hline \multirow[t]{4}{*}{24.02 .2009} & Kondpaturu (D) & 0.90 & 8.36 & 3.40 \\
\hline & Pedanandipadu (D) & 0.85 & 8.13 & 0.60 \\
\hline & Returu (D) & 0.64 & 7.94 & 2.10 \\
\hline & Kommamuru (Canal) & 0.59 & 8.00 & 1.90 \\
\hline \multirow[t]{4}{*}{12.03 .2009} & Kondpaturu (D) & 0.72 & 8.60 & 1.24 \\
\hline & Pedanandipadu (D) & 0.82 & 8.46 & 1.59 \\
\hline & Returu (D) & 0.62 & 8.21 & 0.99 \\
\hline & Kommamuru (Canal) & 0.58 & 8.51 & 1.35 \\
\hline \multirow[t]{4}{*}{24.03 .2009} & Kondpaturu (D) & 0.90 & 8.59 & 2.53 \\
\hline & Pedanandipadu (D) & 0.89 & 8.19 & 2.82 \\
\hline & Returu (D) & 0.80 & 8.27 & 2.32 \\
\hline & Kommamuru (Canal) & 0.58 & 8.45 & 1.49 \\
\hline
\end{tabular}

(D) - Drain

(Source: AICRP, SWS (2009), Bapatla) 

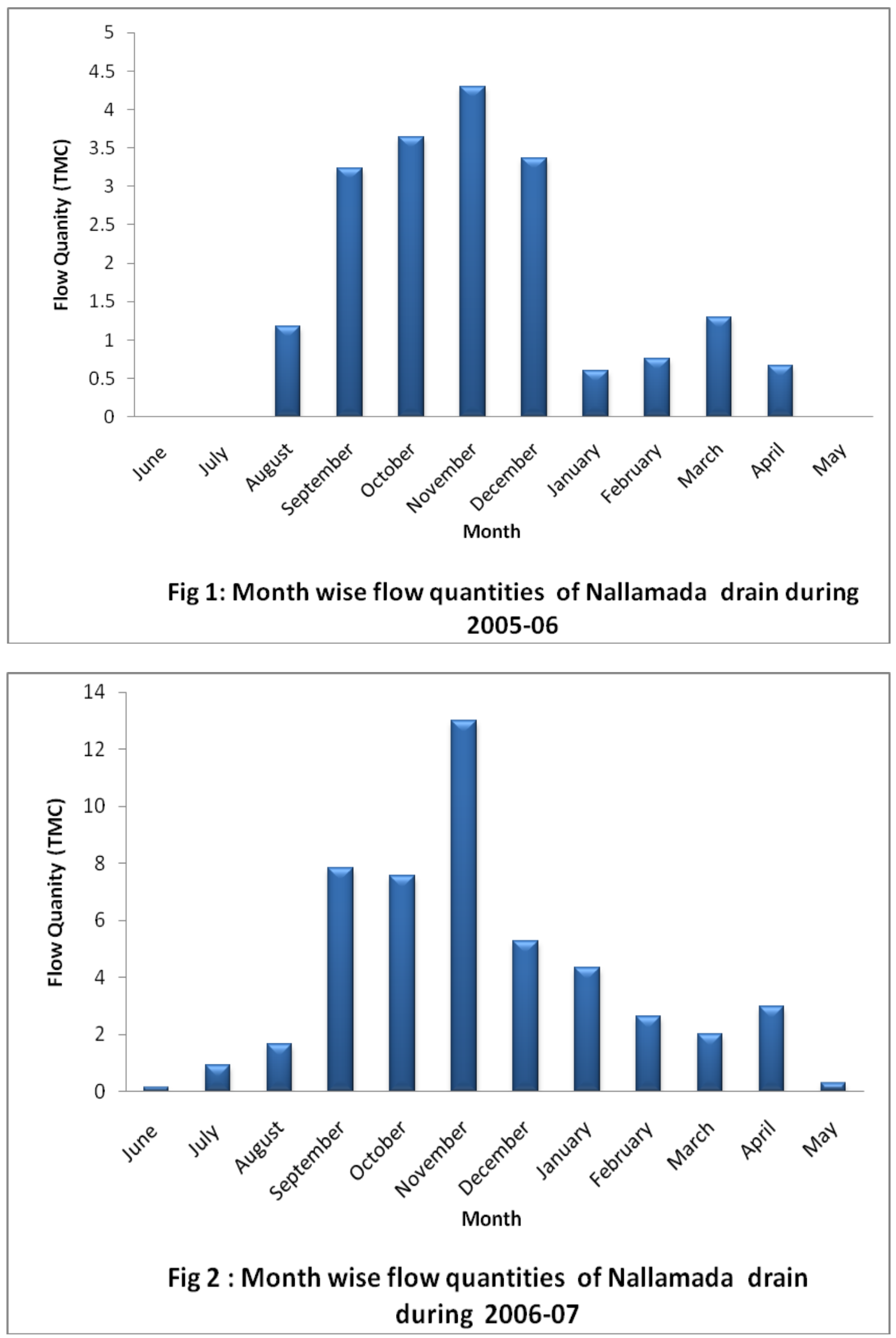

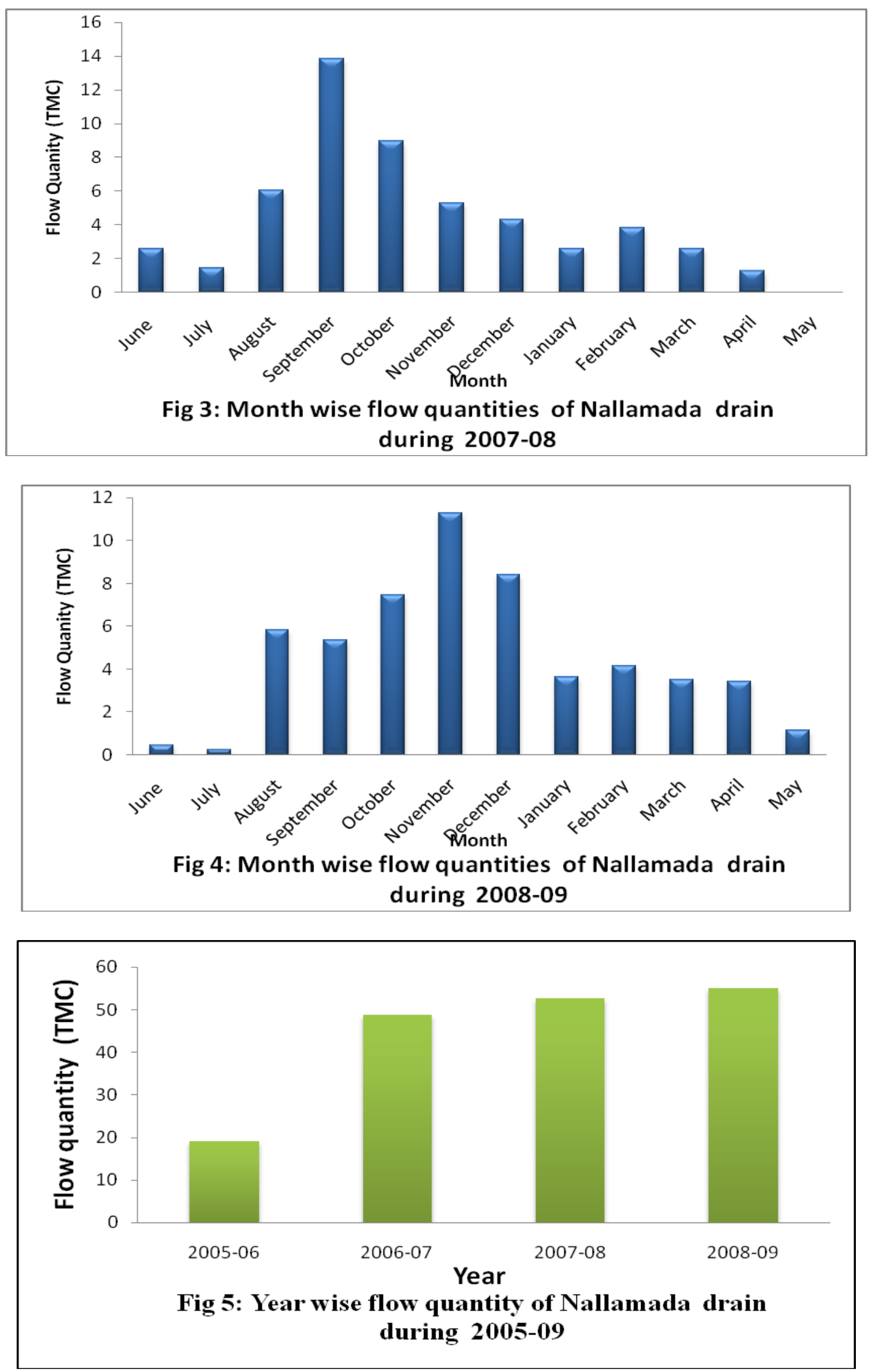


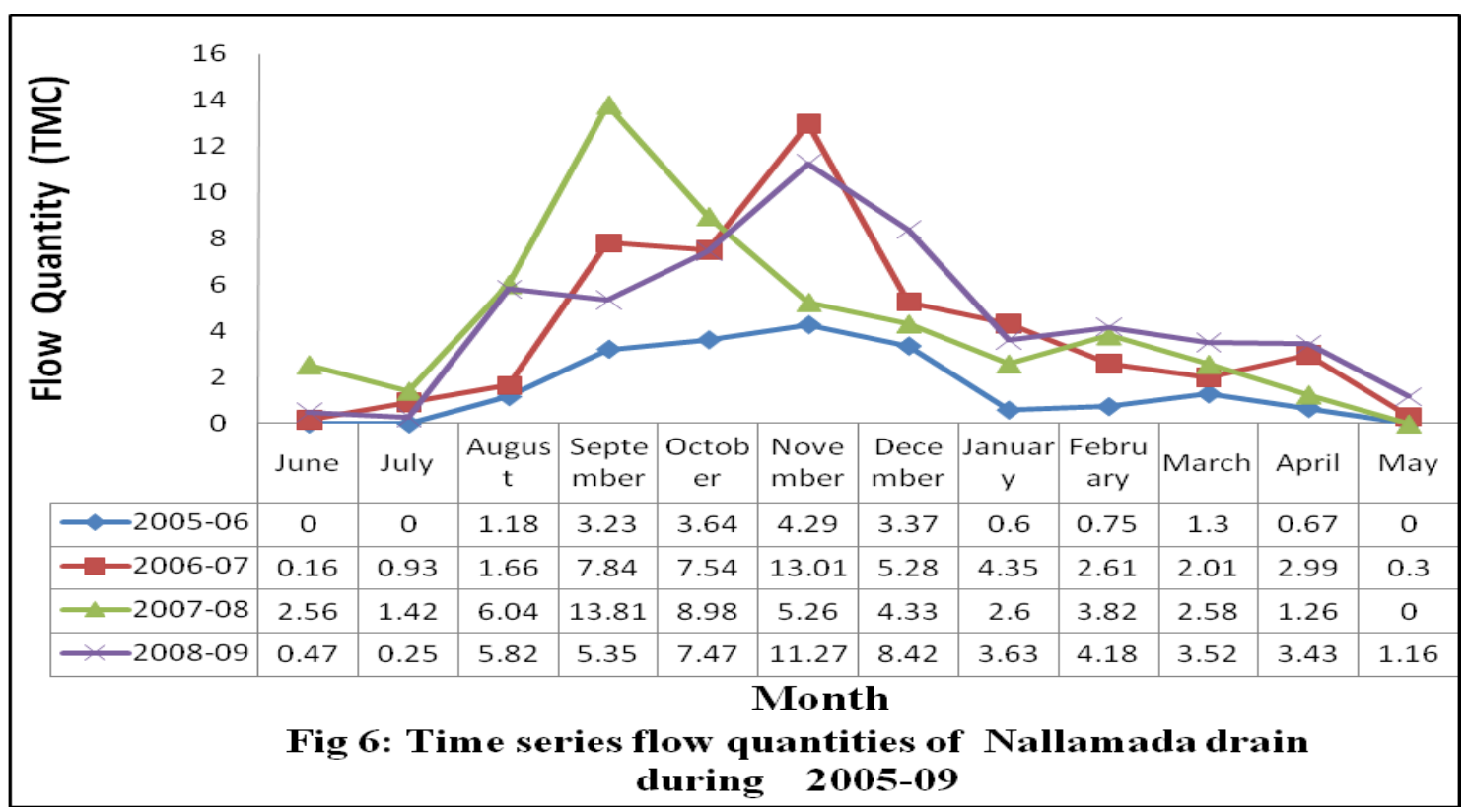

It was observed that on an average about 43.84 TMC of water flows through the drain annually.

The Electrical Conductivity of drain water up to the end of March, 2009 was less than 1.0 $\mathrm{dS} / \mathrm{m}$ indicated that the water was fit for irrigation

The perusal of data indicated that $\mathrm{p}_{\mathrm{H}}$ values of the drain water was estimated to be below 8.0 up to December 2008 and reached to more than 8.0 and below 9.0 during January 2009 March 2009

SAR values were within the safer limit of less than 10.0 and RSC was less than $2.50 \mathrm{meq} / 1$ during September 2008 - March 2009.

The Nallamada drain inflows abundant good quality of water, which can be effectively utilized for irrigation through Lift Irrigation
Schemes for upland command of Krishna Western Delta.

\section{References}

Purushothama, R., Kiran, B.R., Kumar, K.H., and Narayana, J. 2005. Water quality status of Keladi tank at Sagur taluk, Karnataka. Environment and Ecology, 23(3): 541-544.

Siyardhepe, and Madhulika, B., 2005, Effect of Mixed industrial effluent on Soil properties and survival of trees seedlings. Journal of Indian Society of Soil science. 53(1): 137 -141.

Vijaykumar, Omkar singh, Prabakara, J, and Jain, S.K., 2005. Water quality of lift irrigation schemes on streams fedby effluents near Jammu, India. Sustainable water management solution for large cities. 257-263.

\section{How to cite this article:}

Rama Rao, A. and Raghu Babu, M. 2018. Study on Quantity and Quality Aspects of the Drain Water of Nallamada Drain in Krishna Western Delta. Int.J.Curr.Microbiol.App.Sci. 7(10): 2077-2084. doi: https://doi.org/10.20546/ijcmas.2018.710.239 